\title{
The Laying of the Memorial Stone of the New Wing
}

\section{H. R. H}

To cite this article: H. R. H (1893) The Laying of the Memorial Stone of the New Wing, Royal United Services Institution. Journal, 37:185, 711-712, DOI: 10.1080/03071849309416557

To link to this article: http://dx.doi.org/10.1080/03071849309416557

\section{册 Published online: 11 Sep 2009.}

Submit your article to this journal $\pi$

Џ Article views: 2

Q View related articles $₫$ 


\section{(1) \\ or tox

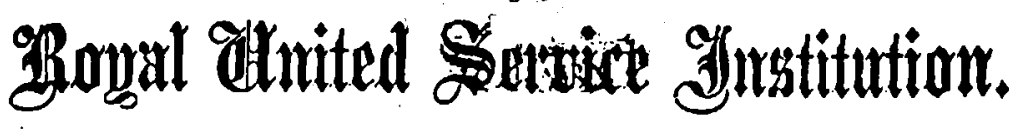

VoL. XXXVII. JULY, 1893.

-No. 185.

\section{THE LAYING OF}

THE MEMORIAL STONE OF TIIE NEW IVING

DY

H.R.II. The Prince of WaLes, K.G.

Sx the Gth of June, 1S93, the memorial stone of the new wing of the Royal United Service Institution was laid by H.R.H. the Prince of Wales, K.G.

The ceremony was performed in a marquee covering the site of the now lecture thentre, library, and offices of the Institution, aldjoining the building hitherto known as the Banqueting IIouse, Whitehall, which will hereafter be the inuseum of the Institution.

Guards of honour, furnished by the Royal Navy and the Coldstream Guards, were drawn up at the north entrance, and the yround in Horse Guards' Arenue was lined by detachments of the 2nd Life Guards, the Pensioners of the Royal Hospital, Cuclsea, and by the boys of the Royal IIospital School, Greenwich, and Duke of York's Royal Mrilitary School.

Their Royal Highnesses the Prince and Princess of Wales were received by H.R.II. the President of the Instilution (Field Marshal the Duke of Cambridgc), the Chairman (General G. Erskine), Vice-Chairman (Admiral II. Boys), and Members of the Council, and by the Chairman of the Bazaar Committce (II.S.II. Prince Edward of Saxe-Weimar) and the Nembers of the Committec, roL. XצITIL. 


\section{LAYING THE JEMORIAL STONE OF THE NEN WINO.}

and were conducted to the dais erected in the marquee, where many of the members of the liojal family were assembled.

The National Anthem having been sung, and prayers having. been offercd by His Gmee the Archbishop of Canterbury; the Chaplain of the Fleet, and the Chaplain-General, H.R.H. the President of the Institution presented an address, after which H.R.II. the Prince of Wales laid the memorial stone and declared it to be: well and truly laid.

H.R.H. the l'rincess of Wales then received purses contnining sums of money presented to the building fund, after which, at the request of II.S.II. the Chairman of the Bazaar Committee, Ilis Royal Highness the Prince of Wales opened the bazaar in aid of the building fund, which was held in the future museum of the Institution. 